\title{
Cultural Barriers in the International Business Negotiation
}

\author{
Sun Xiuli \\ Huanghuai University \\ Zhumadian City ,Henan Province, China
}

\begin{abstract}
With the rapid development of economic globalization, business activities and information exchanges between people from different cultural backgrounds have been increasing rapidly. And cross-cultural business negotiations are playing an important role in the business activities. However, cultural barriers that often occur in the crosscultural business negotiations have become a stumbling block for negotiators from different countries. So how to overcome cultural barriers seems to be more and more urgent and important. In terms of the current situation, this paper firstly gives a brief introduction to business negotiation and culture. Then it relates to three reasons why cultural barriers can happen from the perspective of social custom, values and ways of thinking and non-verbal communication. Finally, this paper puts forward several measures to overcome cultural barriers in the cross-cultural business negotiations.
\end{abstract}

Keywords- business negotiation; cultural barrier; crosscultural

\section{INTRODUCTION}

International business negotiations refer to that they take place between the interest groups from different counties or regions. It is an important activity frequently involved in foreign and other economic exchanges, serving as a critical approach and method for these interest groups or individuals to confer together to reach an agreement or settle their interest conflicts(Samovar Larry A. \& Porter Richard E, 2007:10). The main negotiation parties belong to different countries or regions. The negotiators represent the interests of different countries or regions. At the same time, as international business negotiations are cross-cultural.

\section{THE REASONS OF CULTURAL BARRIERS IN THE Cross-Cultural Business Negotiations}

\section{A. Ways of Thinking Barrier}

Each kind of culture has its own special system. The oriental and western cultures are the two typical cultures in the world. Nowadays, the two cultures always collide with each other. Since the ancient time, people from the two different cultures have formed their own philosophical approach and universal outlook. The westerners prefer abstract universal principles while East Asians seek rules appropriate to a situation (Philip R Harris, 1987:234-260). For example, when researchers in the Nether Lands, they asked people what to do about an employee whose work has been subpar for a year. After 15 years of tracking survey, the researchers found that more than $75 \%$ of Americans and Canadians said that they will let her go; only $20 \%$ of Singaporeans and Chinese will do so. Different modes of thinking between the East and the West have given rise to some tense business conflicts.

\section{B. Values Barriers}

Values refer to important and lasting beliefs or ideals shared by the members of a culture about what is good or bad and desirable or undesirable. Values have major influence on a person's behavior and attitude and serve as broad guidelines in all situations. Samovar, a distinguished scholar, says, " Most people from China, Cuba and some countries and regions in Africa always hold the idea that the enterprise and the means of production should belong to a country or a group. On the contrary, people who were born in America and Canada tend to think that the means of production should be in the possession of an enterprise or a corporation's boss(Samovar Larry A. \& Porter Richard E, 2007:242)." In a society with capitalist system, it is the life goal of most people to make money as much as they can, which make them become individualism-minded. Individualism stresses man's subjective initiative, independence and privacy. However, collectivism is any philosophic, political, religious, economic or social outlook that emphasizes the interdependence of every human being in a society or civilization. Collectivism stresses the importance of cohesion within social groups.

\section{Social Customs Barrier}

Social customs refer to a country or region's traditional convention, rituals and habitual practices. As social customs are formed through ages in the course of history, they have a significant effect upon social members. Social customs 
mainly contain national customs, festivals and traditional rituals. Nowadays, business negotiations are not only an economic activity but also a form of cultural exchanges and communications. Different countries have different social customs. So, for the negotiators, it is very important for them to have a good knowledge of their counterpart's social customs in the international business negotiation and that will greatly increase the rate of success of the negotiations.

\section{Non-verbal Communication Barriers}

In the international business negotiation, the negotiating parties communicate with more than the words they speak. Words are only one part of communication. The negotiators can express their views and feelings by way of non-verbal signals such as gestures, body language and facial expressions. To people of different cultures, these non-verbal signals may have different meanings. In eastern Asian countries, people do not readily show emotions. They are conditioned to use the face to conceal rather than reveal their feelings. For example, the Japanese smile is not necessarily a spontaneous expression of amusement, but a law of etiquette, elaborated and cultivated from early times. It is a silent language, often seemingly inexplicable to Europeans, and it may arouse violent anger in them as a consequence.

\section{STRATEGIES TO DEAL WITH CULTURAL BARRIERS IN INTERNATIONAL BUSINESS NEGOTIATIONS}

\section{A. To Strengthen the Awareness of Cross-cultural Negotiation}

International business negotiation is a negotiation that will involve thinking patterns, behavior and emotion of negotiators (Dawson, W. Hendon, Rebecca Angels Hendon \& Paul Heb, 1996:45). Compared to the negotiation that occur in the same cultural background, the cross-cultural business negotiation is more challenging and complicated, because in the procession of negotiation, various cultural factors must be taken into the international business negotiation. So negotiators must strengthen their awareness of cross-cultural negotiations and culture. The negotiators also need to be cultural sensitive and always bear in mind that a foreign negotiator is different from their own people, not only in physical features, motivations beliefs and values. A wise negotiator understands that being different does not denote being superior or inferior to his counterpart. Of course, there is no need to try to fully adapt to the other sides culture. It is essential that negotiators share the culture and values of the country they represent, otherwise they will not be trusted by their own side (Carry, Jeffrey Edmund, 2004:245-247).

\section{B. To Overcome the Language Barrier}

Cross-cultural negotiations require negotiators to master the language of the other side and know their culture very well. Mastering the language of the other negotiating party contributes to the success of the negotiations. Language barrier is a stumbling block in the cross-cultural business negotiation because it can probably bring about misunderstandings between negotiators, even lead to the failure of negotiations (M. W. \& J. Koester, 2006:101). However, mastering the language of a country is not simply limited to understanding its literal meaning. It also requires negotiators to know some certain words and phrases denotation. Sometimes different cultures use identical words that have rather different meanings. The results can be humorous, annoying, or costly, depending on the circumstances. The same word may have different meanings in different countries. So we must pay more attention to language barriers and try to remove them.

\section{To Make Full Preparations for the Negotiation}

It is very important for negotiators to have a good knowledge of cultural norms, social customs, and values of their counterparts. In doing so, negotiators can make their negotiation move smoothly and avoid unnecessary misunderstandings and conflicts. A successful negotiator is always doing enough preliminary work for his negotiation, just as the saying "Success always favors the prepared mind." Once, an American businessman found an ideal Chinese enterprise through years of market investigation. In order to engage in business relations with the enterprise, he decided to pay a visit to its boss. Since he learned that a gift to his potential partner could better express his sincerity in China. He decided to buy a gift for his partner. At first, he intended to give a bottle of maotai as a gift, a kind of wine which sells at a very high price. But later he gave up the idea because that would make his partner misunderstand that he loved to drink. Finally, he decided to give his potential partner a carton of expensive cigarette as a gift because he thought that all Chinese people are fond of smoking. However, his potential partner hated smoking too much. As a consequence, he failed to build business relations with the enterprise. 


\section{CONCLUSION}

With the increasing development of a global economy, more and more people have come to realize that crosscultural business negotiation is playing an important part in the international trade. However, there always exist uncertainties and challenges in the cross-cultural business negotiation because negotiators from different countries have different ways of thinking beliefs, values and religious beliefs, any of which may become a stumbling block during the negotiation. So how to remove these potential barriers is becoming in particular important. First of all, we should accept and respect other nations' cultures, never generating in prejudice against them while carrying forward fine cultural tradition of our nation. In addition, we should have a profound study of the essence of other nation's culture and find out the similarities and differences between ours and theirs. In the end, we should have a good knowledge of negotiating skills, proper strategies and negotiating styles. If we can make full use of these skills and strategies, we will achieve great success in the cross-cultural business negotiation.

\section{References}

[1] Carry, Jeffrey Edmund. International Negotiating [Z]. Shanghai : Shanghai Foreign Language Education Press, 2004:245-247.

[2] Dawson, W. Hendon, Rebecca Angels Hendon \& Paul Heb. Crosscultural Business Negotiation [Z]. USA: Greenwood Publishing Group, 1996:45.

[3] M. W. \& J. Koester. Intercultural Competence: Interpersonal Communication Across Cultures [Z] (5thed.) Pearson Education, Inc, 2006:101.

[4] Philip R Harris. Managing Cultural Difference [M]. USA: Gulf Publishing Company, 1987:234-260. 